\title{
Características do Presidencialismo no Brasil e Fragilidade Democrática: Dificuldades de Controle do Presidente da República no Brasil
}

\section{Characteristics of the Presidential Government System in Brazil and the Democratic Fragility: Control Difficulties of the President of the Republic in Brazil}

\author{
Marcos Antônio Striquer Soares ${ }^{1}$
}

\begin{abstract}
Resumo
O objeto de estudo do trabalho é o presidencialismo brasileiro. A partir de suas características, analisamos diversas competências dos Poderes Executivo e Legislativo. Há uma concentração de competências (ou de poderes) nas mãos do presidente da República, e, além disso, o sistema não tem mecanismos apropriados para atribuir responsabilidade ao chefe do Executivo federal e retirá-lo do cargo. Essa particularidade torna esse sujeito excessivamente forte dentro do sistema, a tal ponto que ele acaba concentrando as decisões quanto aos destinos do Estado. $\mathrm{O}$ bom funcionamento do governo depende muito mais da pessoa que exerce o cargo de Presidente do que das Instituições estabelecidas. Conseqüências destas circunstâncias são a fragilidade democrática e a dificuldade de controle político (e até mesmo jurídico) dos atos do Presidente da República.

Palavras-chave: Presidencialismo, controle do presidente, fragilidade democrática, democracia.
\end{abstract}

\begin{abstract}
s
The objective of this study is the Brazilian Presidential government system. Based on its characteristics, several competencies of the Executive and Legislative powers were analyzed. It was found that there is, on the one hand, a concentration of competencies (or powers) in the hands of the President of the Republic. On the other hand, the system does not have appropriate mechanisms to attribute responsibility to the head of our Federal Executive, to remove him from his position, which makes him excessively strong within the system, to such an extent that he holds all the decisions on the destinies of the State. The good performance of the government depends much more on the person who holds the position of President than on the established Institutions. The consequences of these circumstances are democratic fragility, the difficulty of political control and even judicial control of the President of the Republic in Brazil.
\end{abstract}

Key words: Presidential government system, president control, democratic fragility, democracy.

\footnotetext{
Doutorando em Direito do Estado/Direito Constitucional pela PUC de São Paulo. Professor de Direito Constitucional na Universidade Estadual de Londrina -Email:marcosstriquer@uol.com.br
} 


\section{Introdução}

As características originárias do presidencialismo são encontradas na formação desse sistema de governo, nos Estados Unidos da América. Os colonos não tinham e não queriam os nobres e a monarquia. No entanto, eles criaram um novo Estado e precisavam de um mecanismo eficiente para governar, diferente dos tradicionais, existentes no Velho Mundo. Nesse ambiente nasceu o presidencialismo, um sistema de governo marcado pelo equilíbrio entre os Poderes Legislativo e Executivo. Nele, o líder maior não recebe o cargo por herança, mas também não pode ser retirado dele conforme as tempestades políticas; o Legislativo cria as leis, mas o Executivo pode impedir o nascimento de leis impróprias para o país; o governo é unipessoal, marcado pela predominância do Executivo, o qual depende, no entanto, do Legislativo para conduzir as decisões do Estado. Tudo isto registrado em uma Constituição, Lei Maior, capaz de manter as regras dessa estrutura e dar segurança à sociedade.

O desenvolvimento histórico do instituto trouxe diversas inovações, como não poderia deixar de ser. Verifica-se que ele foi instituído em diversos países e passou a sofrer transmutações a cada recriação, apresentando características que possibilitam por vezes uma democracia, por vezes uma ditadura. Às vezes ele possui forte marca parlamentarista e, muitas vezes, apresenta todas essas características juntas num mesmo lugar (o que parece ser o caso brasileiro). A partir dessas transmutações vamos encontrar esse sistema em vários países, nos quais ele pode dar origem tanto a uma ditadura, como a uma democracia. Na maioria das vezes, porém, ele depende, não das amarras legais existentes para sua manutenção, mas da pessoa que exerce o cargo de presidente.

No Brasil, adotou-se um presidencialismo fortemente influenciado por características do parlamentarismo - nele o chefe de governo tem bastante liberdade para praticar atos de governo, mas podendo sofrer o voto de desconfiança e a queda, caso abuse dessa liberdade. No entanto, nosso sistema tem um mecanismo tipicamente presidencialista, para controle do chefe do Executivo. Isso pode fazer dele um ditador com prazo certo, pois ele tem a liberdade do chefe de governo do parlamentarismo, mas sofre controle característico do presidencialismo. O modelo por nós adotado é frágil, para quem pretende se constituir como Estado Democrático de Direito, pois mantém muitas frestas para desvios do processo democrático. A compreensão do modelo brasileiro depende do estudo de suas características. Vamos, portanto, analisá-las.

\section{A Tripartição do Poder e o Presidencialismo}

A formação do presidencialismo nos Estados Unidos é fruto da teoria da tripartição do Poder estabelecida por Montesquieu. Como bem ensina Maluf(1990, p.245)" a separação entre os Poderes Executivo e Legislativo adquiriu foros de coisa sagrada no regime. A única comunicação entre os dois poderes fazia-se pela mensagem escrita que o Presidente enviava para ser lida no Congresso, por ocasião da abertura de cada sessão legislativa (MALUF, 1990, p. 245). Para Dallari,

[...] a leitura do Livro XI, Capítulo VI, da obra célebre de Montesquieu, 'De L'Esprit ds Lois', e seu confronto com a Constituição norte-americana, revela ter havido muito mais do que simples coincidência. O ponto de partida do notável teórico francês é a recomendação relativa à separação dos poderes, o que foi religiosamente seguido pelos norte-americanos.

No início os americanos levaram ao extremo a idéia de independência entre os Poderes. Para Russomano(1997,p.128),

O presidencialismo, fundamentalmente, caracterizase pela separação de Poderes. Embasado no pensamento de Montesquieu, que aperfeiçoou a doutrina, consagrando-a em definitivo, considera os órgãos estatais tripartidos e independentes, cabendo a cada um sua função específica .

Para Bastos, 1994b, p.158) não há exatamente uma separação entre os Poderes, "o presidencialismo 
caracteriza-se como uma não-subordinação do Poder Executivo ao Legislativo. O Poder Executivo detém autonomia para o exercício das funções que constitucionalmente lhe cabem". Neste sentido, de autonomia e não subordinação, pode-se considerar a interdependência entre os Poderes, o que não propõe a separação, mas a harmonia entre eles.

Esse equilíbrio entre as funções do Executivo e do Legislativo é a própria essência dos sistemas de governo - parlamentarismo, presidencialismo ou diretorial. Isto porque é através daqueles que se estabelece a relação entre estes órgãos governamentais do Estado: busca-se, por esses mecanismos, a convivência harmônica e equilibrada, sem a predominância de um órgão ou uma autoridade. Contudo, é uma missão quase impossível, embora os americanos tenha chegado a bom termo. Para Schwartz (1966, p. 114-115), estabelecer um Executivo nacional que seja bastante forte para tratar eficazmente dos problemas da nação e, ao mesmo tempo, não tão forte que tenda a suplantar os outros dois ramos do Governo (o Legislativo e o Judiciário) parece uma tarefa tão impossível quanto a quadratura do círculo. Mas, para ele, os sistemáticos fluxos e refluxos do poder presidencial falam em favor dos elaboradores da Constituição americana nos seus esforços de estabelecer um Executivo bastante forte para pelejar pelos interesses da nação, mas não tão forte que a nação não possa pelejar contra ele.

É importante salientar, aqui, a repercussão do presidencialismo mundo afora, para entendê-lo no Brasil. Verificamos, pois, que a Constituição americana chegou a bom termo para essa relação entre Executivo e Legislativo, contudo, os demais países que instalaram esse sistema de governo não copiaram o instituto original em sua íntegra. Cada país que o adotou fez adaptações conforme conveniências locais.

Decorre daí uma verificação perigosa. Em muitos lugares, desapareceu o equilíbrio entre os Poderes, vindo a prevalecer o Poder Executivo, gerando muitas ditaduras, marcadas pelo predomínio do poder pessoal ou de grupos. Isto não é uma possibilidade. É história recente em nosso país e em vários outros no mundo.

Desaparecendo a tripartição do Poder, já não existirá o presidencialismo, mesmo que formalmente prescrito em lei. Conforme o estabelecido na legislação de cada país, existirá ditadura, caso prevaleça o Executivo, ou haverá parlamentarismo, caso o poder se desloque para o Legislativo. Um presidencialismo como "fachada" - característico do Brasil de hoje - prescrito oficialmente em lei, mas com legislação disfarçando um parlamentarismo, ou levando à possibilidade de uma ditadura (em razão do excesso de competências autorizadas ao presidente) é sempre muito perigoso, pois o povo fica a depender muito mais das autoridades que exercem os cargos do que das Instituições do Estado.

Bastos(1989, P.89-90) ensina que, no presidencialismo, desaparece a importância do Presidente contar com a maioria no Legislativo, pois ela não constitui fator decisivo para sua manutenção no cargo:

o presidente da república dispõe dos meios
necessários para manter-se no cargo e executar as
leis. Um bom êxito global da sua política vai
depender, é certo, de um bom relacionamento com
o Legislativo, único meio que lhe pode assegurar a
realização integral da sua política, uma vez que essa
sempre dependerá de leis e da aprovação de verbas
que a custeie.

Essa trecho deixa claro o que significa independência dos Poderes e quanto a harmonia entre eles depende das pessoas que exercem os cargos.

\section{Período de mandato fixo e impeachment do presidente}

Por outro lado, a tripartição do Poder também fica marcada em razão do mecanismo utilizado para atribuir-se responsabilidade ao presidente, qual seja, o impeachment. A existência dele, no entanto, pressupõe um período fixo de mandato presidencial, dentro do qual o afastamento do presidente é uma exceção. $\mathrm{O}$ órgão legislativo não pode provocar o 
afastamento do chefe do Executivo de suas funções. Para atingir esse 'desideratum', precisa estar embasado num crime (praticado por aquele titular) (RUSSOMANO, 1997, p. 128). O mecanismo para se atribuir responsabilidade ao presidente, portanto, não é um cheque em branco dado ao Congresso, pelo contrário, exige-se a comprovação de atos de afronta a lei, o chamado crime de responsabilidade política ou, simplesmente, crime político.

A Constituição brasileira fixa esses crimes em seu art. 85 e o procedimento de cassação no art. 86 (a lei 1.079, de 10-4-1950 define os crimes de responsabilidade e regula o respectivo processo de julgamento). O julgamento é político e se realiza no Senado. Deve-se esclarecer, porém, que apesar do julgamento ser político ele só se realiza se houver provas do crime praticado pelo presidente. Havendo provas, pode haver o julgamento, porém, sendo política, a decisão será tomada em razão da conveniência ou oportunidade da cassação. Por mais evidentes que sejam as provas, elas não conduzem a um "dever ser" de condenação do presidente, pois esta depende da conveniência ou oportunidade da cassação (acerca do controle político do presidente e até mesmo sobre julgamento dele, remete-se o leitor para o item 1.3.6, infra, sobre "O Poder Legislativo e controle sobre o Poder Executivo: controle da legalidade e controle político".

O procedimento de cassação, contudo, é de tal modo recheado de entraves, de dificuldades para seu andamento, que poucas vezes na história ele chegou a bom termo para corrigir erros nesse sistema de governo. Temos apenas dois exemplos, ambos recentes. A cassação de Fernando Collor, no Brasil denunciado pelo próprio irmão em uma revista de circulação nacional, e a de Abdurrahman Wahid, na Indonésia, este no dia 23 de julho de $2001 .^{2}$

Como julgamento político que é, essa cassação depende do apoio popular e de grupos sociais, para ser bem sucedida. Caso isso não ocorra, a tendência é a manutenção do presidente no cargo, as vezes até havendo prova de crime de responsabilidade, mas com um fiscalizador (Legislativo) conivente com os atos e os interesses do Executivo. Sem mobilização da opinião pública e sem o apoio popular e de grupos sociais (associações de classe, de bairro, sindicatos, entre outros), é quase impossível a cassação do chefe do Executivo em nosso sistema de governo. Isso aconteceu com Fernando Collor, mas depois de inúmeras denúncias apresentadas por seu irmão.

Essa dificuldade para a utilização do impeachment acaba proporcionando uma prevalência do Executivo sobre o Legislativo, em países de pouca tradição democrática. Porém, é um instrumento poderoso num presidencialismo fincado em boa democracia, pois sua existência é suficiente para impor comportamentos, como foi na renúncia do Presidente Nixon, dos Estados Unidos, em razão do caso Watergate. Não se pode esquecer, contudo, que presidencialismo e democracia bem sedimentada é um casamento pouco encontrado na história.

A eletividade dos representantes do povo é característica de uma forma de governo: A República. Dentre as formas de governo o mandato do eleito influencia a relação entre Legislativo e Executivo à medida que o primeiro pode ou não afastar o chefe do segundo. Assim, o mandato do eleito interessa no presidencialismo porque ele é fixado com prazo certo, e a responsabilização do presidente cabe apenas nos casos de crime político. Assumindo o cargo por prazo certo, dificilmente será retirado do cargo, quando respeitado o Estado de Direito. Por outro lado, num sistema onde não haja equilíbrio entre os Poderes( o que se afasta das características próprias do presidencialismo), a dificuldade de cassação do chefe do Executivo fortalece perigosamente esse sujeito.

\footnotetext{
2 Jornal O ESTADO DE SÃO PAULO, 24 de julho de 2001, p. A11.
} 


\section{A irresponsabilidade política do presidente}

O presidencialismo tem um mecanismo de tripartição do Poder de tal modo estabelecido que podemos falar em uma irresponsabilidade política do presidente perante o Legislativo. Segundo Maluf(1990, p.244).

Uma vez eleito e empossado na forma legal, passa a governar com autoridade própria, por todo o período previsto na Constituição, semelhante a um Rei eletivo e temporário. Todo o governo será o reflexo de sua individualidade. [...] Nisto consiste o princípio da irresponsabilidade política, característico do presidencialismo: por erros, desmandos ou incompetência (que não configurem crimes no conceito específico da lei penal) não se dará a perda ou cassação do mandato.

A independência do Executivo em relação ao Legislativo é tão marcante para o autor que ele chega a indicar semelhança entre o presidencialismo e a monarquia. Essa semelhança está, em verdade na origem do sistema de governo, mas já não é razoável para os nossos dias.

Para Bastos(1989, p.89), a teoria da separação de Poderes apresenta :

o traço fundamental do presidencialismo, qual seja, a irresponsabilidade do presidente da república, perante o Congresso. A palavra irresponsabilidade tem aqui um sentido bem específico. Ela significa, tão-somente, que o presidente da república não necessita do apoio do Congresso para manter-se no poder. Ele vem-lhe às mãos por meio de uma eleição popular, que lhe confere um mandato .

É claro que é possível a cassação do presidente por meio do impeachment, o que será estudado em seguida, mas este é um instrumento para se verificar a existência do chamado crime de responsabilidade do presidente, o que pressupõe o desrespeito à lei. Quando falamos em irresponsabilidade política, falamos em comportamento dentro da lei.
Essa afirmação de irresponsabilidade política encontrada na doutrina não significa que o exercício do poder possa ultrapassar os limites da legalidade. Pelo contrário, num Estado de Direito a Constituição e a lei são limites para todo e qualquer indivíduo, inclusive, e principalmente, para os exercentes de cargo público. Irresponsabilidade, aqui, significa total independência na condução dos negócios do Estado. Significa que se o presidente propõe um programa de governo impróprio para sua realidade e conduz sua sociedade ao caos, ele não poderá ser cassado por isto. Ele não poderá ser cobrado por seus atos políticos, por seus erros quanto a propositura e condução desse programa de governo ${ }^{3}$. Não há, sob o aspecto jurídico, como se exigir comportamentos políticos do presidente. Ele foi eleito para o cargo e o julgamento por seus erros políticos, na condução dos interesses do Estado, caberá ao povo, na próxima eleição presidencial.

\section{Poder Executivo e produção legislativa no presidencialismo}

O presidencialismo é um sistema de governo que se baseia na teoria tripartição do Poder, demarcando as competências de cada um dos órgãos fundamentais do Estado, por isso ele, originariamente, não aceita, com a exceção do veto, a participação do presidente no processo de produção de leis. Como reflexo dessa independência, nos Estados Unidos da América do Norte - onde o mesmo foi concebido em sua feição mais pura - , a iniciativa da legislação ficou entregue tão-só ao órgão próprio, cabendo a interferência presidencial no processo legislativo apenas no atinente ao direito de veto (RUSSOMANO, 1997, p. 129). O Presidente da República não tem a iniciativa de leis, sendo que, nos Estados Unidos, para suprir essa proibição o Presidente envia todos os anos a sua 'Mensagem sobre o estado da União', justamente para dar conta

\footnotetext{
3 Vem à lembrança, aqui, a condução dos interesses da Argentina nos últimos anos (década de 90 e início do século XXI) e a irresponsabilidade política de seus dirigentes em relação às conseqüências desastrosas enfrentadas por aquele país.
} 
ao Congresso das suas necessidades legislativas (ACCIOLI, 1985, p. 373). A produção da lei, assim, fica a cargo do Poder Legislativo.

Bastos (1989, p. 89-90) explica que:

o presidente não tem participação quase nenhuma no processo legislativo. Não lhe é dado propor leis ao Congresso americano, embora sempre surjam formas de fazer sentir à Casa de Leis os bons olhos com que veria a propositura dessa natureza, nesse ou naquele sentido. Explica, porém, mais adiante, que um êxito global da sua política vai depender, é certo, de um bom relacionamento com o Legislativo, único meio que lhe pode assegurar a realização integral da sua política, uma vez que essa sempre dependerá de leis e da aprovação de verbas que a custeie.

Percebe-se nessas palavras, que o presidente não tem participação no processo legislativo, mas exerce grande influência em sua formação.

Essa grande influência também é salientada por Aderson de Menezes, que a relaciona como uma das características do sistema:

O terceiro traço fundamental se relaciona com a proposta de legislação feita pelo chefe do executivo, a qual, ainda que não explicitamente disciplinada na lei suprema dos norte-americanos, vem sendo usada, a tal ponto que o presidente, como colaborador da atividade legiferante, pode sugerir projetos, especialmente quanto à concessão de verbas para necessidades imperiosas. De resto, nas modernas constituições presidencialistas, estão compendiadas certas iniciativas de leis privativas do chefe do executivo .

Registra-se, aqui, a influência que o chefe do Executivo vem exercendo sobre o Legislativo. Essa influência, é meramente política nos Estados Unidos, mas passou a ser demarcada pela lei, em outros países presidencialistas do mundo.

Essa influência é tão evidente hoje, que Maluf (1990, p.244) indica várias atividades legislativas do Executivo:

Além das funções executivas o Presidente da República está investido de importantes funções legislativa, como sejam: a) direito de iniciativa de qualquer projeto de lei; b) direito exclusivo de iniciativa de determinados projetos de lei, de ordens administrativa, econômico-financeira, militar etc.; c) competência para praticar os atos conclusivos e integrativos da lei - promulgação, sanção e publicação; d) direito de veto .

A trajetória da influência do presidente sobre o Legislativo, nos Estados Unidos, é registrada por Schwartz (1966, p. 131 - 133) em três estágios distintos. Num primeiro momento, a participação dele na elaboração da lei restringe-se ao poder de veto e no envio de mensagem anual ao Congresso sobre o estado da União e também uma mensagem orçamentária. $\mathrm{O}$ veto nem sempre é de natureza simplesmente negativa, constitui também um instrumento positivo para que o Presidente demonstre a sua liderança legislativa. [...] A ameaça da rejeição presidencial contribui às vezes para impedir que o Congresso contrarie os desejos do Executivo. Quanto a mensagem anual, o programa legislativo desejado pelo Executivo é então traçado, sendo que as mensagens anuais têm grande efeito na aprovação da legislação. O presidente tinha somente estes instrumentos de comunicação com o Congresso. A tripartição do Poder era mantida, contudo esse foi o período do Estado mínimo, do liberalismo, época em que a atividade do Estado era bastante reduzida e pequena a necessidade de comunicação entre presidente e Congresso. Num segundo estágio, vem a descoberta da mídia e do respaldo popular como instrumento de pressão sobre o Legislativo, para aprovação de leis conforme propõe o Executivo. Continua Schwartz (1996, p.133):

A tribuna nacional está sempre à disposição do Presidente que deseja obter o apoio popular para o seu programa. Os grandes Presidentes dos últimos 50 anos foram, na expressão de Franklin D. Roosevelt, 'líderes morais, cada um a sua própria maneira e para a sua própria época, que usaram a presidência como um púlpito'. O Presidente pode sempre combater a oposição do Congresso levando o seu caso diretamente ao povo. [...] Hoje, o uso efetivo da televisão e do rádio dá-lhe a certeza de que o seu caso será ouvido e conhecido como ele o deseja que seja ouvido e conhecido. Se o 
Presidente pode atrair a opinião pública para apoiar o seu programa, não é um Congresso obstinado que conseguirá resistir à aprovação de determinadas leis.

São mecanismos do século $X X$, portanto registramos a liderança moral do Chefe do Executivo e o acesso às grandes massas. O presidente, então, não ganha iniciativa de lei, mas exerce seu carisma e seu respaldo popular para exigir comportamentos do Legislativo. Põe-se em relevo a personalidade do presidente. Importa aí a liderança exercida por uma pessoa, sua legitimidade no sentido político e não a legitimidade formal da norma jurídica. Por fim, nas últimas décadas, houve uma tendência crescente para que a legislação mais importante se originasse no Executivo. Citando Galloway (apud SCHWARTZ ,1996, p. 134) explica: "À medida que os problemas administrativos se tornaram mais técnicos, o Congresso passou a recorrer cada vez mais ao Executivo, a fim de se orientar na elaboração das leis. Então, conclui o autor: atualmente, a elaboração da legislação pelas repartições do Executivo se tornou norma comum". Assim, mesmo não propondo os projetos de lei, a fonte de projetos de lei encontra-se no Executivo que exerce, então, grande influência sobre o Legislativo.

Com base nessas passagens de Schwartz (1996) verifica-se a crescente influência do presidente na criação legislativa. Contudo, sua influência ainda está condicionada a liderança exercida pela pessoa do presidente. A tripartição do Poder está mantida. Não aconteceu, como no resto do mundo, especialmente como no Brasil, uma degeneração do papel do presidente, que recebeu da Constituição e das leis grande quantidade de atribuições para interferir no processo legislativo. Aqui temos mesmo a degeneração do presidencialismo, que pode saltar para uma ditadura temporária - prazo do mandato ou até mesmo para uma ditadura como foi a dos militares - sem muitas dificuldades.

Merece realce em nosso país, a competência atribuída ao presidente da República para deflagrar o processo legislativo. Isto está fixado nos arts. 60 ,

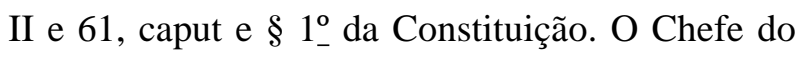
Executivo, no Brasil, tem competência para propor a modificação da estrutura de poder do Estado, propondo emendas constitucionais, embora não possa exercer poder de veto sobre projeto de emendas constitucionais. Por outro lado, a iniciativa de leis complementares e ordinárias se apresenta como um poderoso instrumento nas mãos do Presidente, pelo qual ele pode levar ao Congresso Nacional sua proposta de governo, com todos os elementos necessários para levar a bom termo seu projeto. Conjugando a iniciativa de lei com o poder de veto, verificamos uma hegemonia do Executivo, pois ele apresenta sua proposta de governo, através da iniciativa de lei, e veta aquelas propostas legislativas que destoem de seu programa de governo.

\section{$O$ poder de veto}

O veto é um instrumento com o qual o presidente pode impedir a conclusão de um projeto de lei. Aposto, a Casa Legislativa deverá fazer um novo exame da matéria, derrubando ou não o veto. Segundo Ferreira Filho (1999, p.197).

o veto, em nosso Direito, é suspensivo ou superável. Não é ele um ato de deliberação negativa, do qual resulta a rejeição definitiva do projeto, conseqüência do chamado veto absoluto, mas é ato de recusa, do qual resulta o reexame do projeto Legislativo, que poderá superá-lo por maioria qualificada.

O próprio Montesquieu (1979, p.319), previa a necessidade do veto, para o equilíbrio entre os Poderes:

Se o poder executivo não tem o direito de vetar os empreendimentos do corpo legislativo, este último seria despótico porque, como pode atribuir a si próprio todo o poder que possa imaginar, destruiria todos os demais poderes. [...]. O poder executivo deve participar da legislação através do direito de veto, sem o que seria despojado de suas prerrogativas. Mas, se o poder legislativo participar da execução, o poder executivo estará igualmente perdido. Se o monarca participasse da legislação pela faculdade de estatuir, não mais haveria 
liberdade. Porém, como é preciso que ele participe da legislação para se defender, cumpre que ele aí tome parte pela sua faculdade de impedir .

O veto é um instrumento típico do presidencialismo, no qual o equilíbrio entre os Poderes do Estado é fundamental:

Somente na Idade Moderna o veto passou por transformação para firmar-se como elemento de equilíbrio dos poderes, primeiramente na Inglaterra, que depois o abandonou, caindo o instituto ali em desuso, em 1701, pelo estabelecimento do regime parlamentar. Isto porque ele só se justifica nos regimes em que o executivo não pode intervir na legislação, e em que a lei é feita pelo parlamento sem que o executivo tenha podido participar eficazmente em sua confecção .

Com o decorrer do tempo, o presidente passou a utilizar o veto como instrumento até mesmo para estatuir, ou seja, até mesmo para impor comportamentos ao Legislativo quando da produção da lei. Com o advento do Estado social, com o intervencionismo de Estado, o veto passou a ser utilizado como um instrumento de atuação positiva do Executivo na condução dos negócios do Estado. Corwin (apud SCHWARTZ, 1966, p.130) esclarece:

deve-se levar em conta que o poder de veto nem sempre é de natureza simplesmente negativa; constitui também um instrumento positivo para que o Presidente demonstre a sua liderança legislativa. O poder de veto tornou-se assim uma ameaça permanente aos patrocinadores de projetos e tem-se constituído num instrumento de negociação para a elaboração de outros projetos em substituição aos rejeitados. A ameaça da rejeição presidencial contribui às vezes para impedir que o Congresso contrarie os desejos do Executivo .

A doutrina também tem-se preocupado com a finalidade do veto. Ernesto Rodrigues (1981, p. 33) aponta algumas encontradas, são elas: impedimento dos excessos e abusos do Congresso (citando Roberto Barcellos Magalhães e Montesquieu); aperfeiçoamento do projeto legislativo, forçando o Poder Legislativo a rever ou reconsiderar o projeto de lei ou parte dele (citando Alcino Pinto Falcão); recurso do Executivo contra as deliberações dos representantes do povo, protegendo o direito individual e coletivo contra as precipitações e abusos do Poder Parlamentar, estabelecendo, para o corpo legislativo, um freio salutar, destinado a resguardar a Nação contra os efeitos das facções, da precipitação ou do impulso contrário ao interesse público e bastante forte par influenciar a maioria do Congresso (MAXIMILIANO apud RODRIGUES,1981).

Essa possibilidade de interferir na produção da lei, contudo, deve ser fundamentada. $\mathrm{O}$ art. $66, \S 1^{\circ}$ da nossa Constituição determina que o veto somente pode ser aposto em razão de inconstitucionalidade do projeto de lei ou em razão de interesse público. Segundo Temer(1990, p..43) tratando de controle da constitucionalidade, a Constituição vigente permite a identificação de 'controle preventivo e repressivo'. O primeiro [...] destina-se a impedir o ingresso, no sistema, de normas que, em seu projeto, já revelem desconformidade com a Constituição. Esse controle é exercido tanto pelo Legislativo quanto pelo Executivo (1990, p. 43). Na seqüência da explicação o autor ensina que, no Executivo, o controle preventivo ocorre quando do veto presidencial.

Já o veto por interesse público é determinado em razão de conveniência e oportunidade. Eleito para um mandato com prazo fixo, com programa discutido e votado em eleições populares, chefe de um governo unipessoal, dotado, ainda, de iniciativa de lei, o presidente da República, no Brasil, é o sujeito que dita os negócios do Estado. O veto por interesse público, nesse ambiente, muito além de controlar os excessos do Legislativo, serve para ajustar a produção legislativa ao programa de governo proposto pelo presidente. Assim, nos dias atuais, o veto se apresenta como um instrumento para consolidar ainda mais a liderança do chefe do Executivo, no presidencialismo, especialmente no brasileiro, desequilibrando, desmedidamente, as forças entre os Poderes do Estado.

\section{A lei delegada e a tripartição do Poder}

A lei delegada é uma espécie normativa criada pelo chefe do Poder Executivo com autorização 
prévia do órgão Legislativo. Depois de falar do veto nos Estados Unidos, Rosah Russomano relata que

mesmo naquele país, a necessidade da legislação extracongresSional se fez sentir de maneira intensa. As novas realidades exigiram a própria delegação legislativa que, embora estabelecida com restrições e cercada de cuidados expressos, se veio a integrar no sistema governamental do país, concretizando uma das múltiplas criações positivas do 'new deal'.

Assim, o presidente passou a produzir leis, porém, dentro de limites previamente impostos pelo Legislativo, que delega competência legislativa a ele. A delegação ocorre de tal modo que o presidente tem liberdade para produzir a lei, mas conforme as restrições e limites fixados no ato de delegação.

No Brasil a lei delegada está prevista no art. 68 da Constituição, que fixa as matérias impróprias para delegação. Desde que autorizado pelo Congresso, o presidente baixa a lei delegada, e o Legislativo somente apreciará a norma produzida antes de entrar em vigor se houver previsão expressa no ato de delegação. Porém, em razão da existência da medida provisória, essa espécie normativa foi pouquíssimo utilizada em nosso país.

A lei delegada é, assim, um instrumento que agiliza a produção legislativa, mas coberta por inúmeras restrições, para evitar o predomínio do órgão Executivo sobre o Legislativo, competente para a produção de leis. No Brasil ela não foi suficiente para a nossa tradição autoritária e criamos instrumentos muito mais ágeis para a produção legislativa via Executivo: o decreto-lei e, depois, a medida provisória. A compreensão do presidencialismo em nosso país passa, necessariamente, por essas espécies normativas, bem como a compreensão da sobrevivência ou não do equilíbrio entre os Poderes.

\section{Outros elementos de desequilíbrio entre Executivo e Legislativo no Brasil}

Sem questionar a origem de nossas práticas políticas, mas consciente de nossa tradição autoritária, registram-se a seguir algumas características observadas em nosso sistema de governo, além de algumas já citadas, que dificultam o desenvolvimento democrático do nosso país, por atribuir competências excessivas a um único sujeito.

\section{A medida provisória}

Um instrumento poderoso dado ao presidente da República no Brasil é a medida provisória. Esta espécie normativa é apropriada para o parlamentarismo, pois serve de instrumento ágil de comunicação entre Legislativo e Executivo. Ocorre que nesse regime não há possibilidade de hegemonia do segundo órgão, já que a verificação da responsabilidade do chefe de governo se dá pelo voto de desconfiança do Parlamento, sem a necessidade de comprovar crime de responsabilidade, como é no presidencialismo. Conjugando a medida provisória com outras características do presidencialismo mandato com prazo certo, governo unipessoal, mandato popular e também o veto - teremos um presidente ainda mais forte do que normalmente o é nos demais sistemas presidencialistas.

A história recente do Brasil comprova esse fato. Como exemplo, pode-se citar os atos arbitrários praticados por Fernando Color de Melo logo em seguida a sua posse. Era o primeiro presidente da República eleitor depois do regime militar, eleito com a maioria absoluta dos votos válidos, portanto, com larga aprovação popular. Conduziu seu governo com atos de evidente ilegalidade. Dentre eles, salienta-se o bloqueio de cruzados, que não foi coibido de imediato pelo Judiciário (acredito que em boa parte em razão de seu mandato popular).

O governante deve encontrar seus limites, caso contrário será bem provável a prática de atos arbitrários. E isso também se deu por ocasião do bloqueio de cruzados, quando o Judiciário sequer tomou conhecimento da medida provisória que proibiu liminar em mandado de segurança. Essa proibição chegou a pontos do absurdo, mesmo naquele instante. Nossa democracia não precisa esperar tanto absurdo para coibir os abusos do nosso chefe do Poder 
Executivo. Precisa-se de instrumentos eficientes de controle dos órgãos governamentais, que evitem o arbítrio, eficientes para manter a legitimidade no exercício do poder.

Com a emenda constitucional número 32, de 11 de setembro de 2001, foram criadas novas restrições à edição das medidas provisórias. Contudo, ela continua sendo um instrumento que pode gerar abusos nas mãos de quem a usa. A sua boa utilização ainda depende muito mais da pessoa que as emite do que das restrições para sua edição. Ainda continua como um instrumento legislativo num sistema de governo onde seu chefe já tem predominância sobre o Legislativo, ou seja, mesmo com a nova emenda constitucional ainda pode ser utilizada pelo presidente como um instrumento de arbítrio.

\section{Infidelidade partidária, distribuição de cargos públicos e emendas no orçamento}

Pode-se juntar à medida provisória outros elementos, que também são encontrados no Brasil: a ausência de fidelidade partidária, a distribuição de cargos do órgão Executivo e as emendas no orçamento.

Por meio de emendas ao orçamento da União, o parlamentar destina recursos financeiros a instituições que indique. Bons parlamentares têm levado esse dinheiro para instituições filantrópicas ou para programas de boa qualidade desenvolvidos por Municípios. Outros parlamentares têm utilizado esse mecanismo para desviar verbas para os interesses pessoais. De qualquer modo, o Legislativo, que tem por função produzir leis e fiscalizar o Executivo, recebe o direito de destinar verbas a quem entenda por bem. Isto tem servido para campanhas eleitorais (tanto para discurso político, para uns, como para arrecadar dinheiro para a campanha, para outros).

Por outro lado, a existência de cargos de confiança ${ }^{4}$ é comum no mundo inteiro, mas no Brasil a distribuição deles é um poderoso instrumento de governo, que centraliza a decisão nas mãos de uma autoridade responsável (direta ou indiretamente) pela distribuição de muitos cargos. A conjugação de ambos parece ir além dos limites de peculiaridades próprias de nosso país, ficando mesmo a um passo do autoritarismo.

Entendem alguns autores que o presidencialismo é o sistema mais adequado para a existência do pluripartidarismo. Segundo Ferreira Filho(1999, p.141):

o esmigalhamento das forças políticas nacionais em inúmeros partidos que se entredevoram por questões de pormenor, sublinhando suas diferenças e intensificando a demagogia para alcançar apoio popular, repercute sempre nas Câmaras onde nenhum dos grupos consegue normalmente maioria sólida, onde nenhuma coligação é estável. O presidencialismo, conclui o autor em seguida, sofre em grau menor os males do pluripartidarismo sem peias. De fato, sendo a eleição presidencial necessariamente majoritária, impõe ela uma polarização das forças políticas. Não podendo ser o Presidente destituído por motivos políticos, o governo não depende em sua estabilidade da confiança parlamentar .

Essa postura, porém, tem a visão da instabilidade gerada em razão da instabilidade entre os partidos. Ela não nos parece a mais acertada.

O grande perigo desse sistema de governo nos parece ser a excessiva atribuição de competências ao chefe do Executivo, detentor de mandato por período determinado. Caso ele seja um louco, todo o Estado ficará demente. Caso ele seja um grande estadista, o Estado poderá ter avanços consideráveis. Ao contrário da visão apresentada por Ferreira Filho (a instabilidade gerada pela fragilidade do pluripartidarismo), discute-se apresentamos aqui a fragilidade gerada pela excessiva concentração de poder nas mãos de um único sujeito.

A história do Brasil trouxe muitos exemplos da instabilidade gerada pela centralização do poder, traduzida em diversas ditaduras. Até hoje sequer

\footnotetext{
4 É possível encontrar dados atualizados sobre o assunto na revista Veja número 1778, de 20/11/2002, pp. 38 a 42.
} 
existiu oportunidade de comprovar o funcionamento dos partidos políticos, pois não se teve períodos democráticos o bastante para tanto. Parece que já houve tentativas suficientes nesse campo para continuarmos tentando. Por outro lado, a instabilidade partidária não é tão grande como conta o autor citado, se isto fosse um empecilho a maior parte dos países realmente democráticos não teriam por base o parlamentarismo.

Nesse campo, portanto, parece ser mais adequado buscar o aperfeiçoamento das instituições nacionais, a partir da constatação de seus vícios. Depois disto se poderá decidir o caminho mais acertado. Desde já pode-se registrar, no entanto, a face oposta dos dados apresentados por Manoel Gonçalves: se de um lado o presidencialismo é o sistema mais adequado para o pluripartidarismo, por outro, também é o mais adequado para a submissão dos parlamentares e partidos ao chefe do Executivo, pois este sujeito concentra poder em suas mãos e inviabiliza o bom equilíbrio no funcionamento deles. A possibilidade da excessiva concentração de poder nas mãos do presidente pode ser minimizada em nosso país com exigência de fidelidade partidária, o que existe apenas de modo formal em nosso direito.

Quanto a fidelidade partidária, já tivemos oportunidade de anotar que:

\begin{abstract}
se o representante do povo pode manter seu mandato mesmo contrariando as regras de seu partido, ou mesmo trocando de partido, ou, pior, mesmo podendo permanecer sem partido, deixamos a ele o arbítrio de aceitar uma sanção e seguir as normas do partido, com disciplina; ou não aceitar a sanção e deixar o partido. É claro que o controle sobre seus atos foge das mãos do partido, pois, sob a possibilidade de uma vantagem pessoal maior, ele pode ir para outro. Nestas condições, tendo em vista a intenção de interferir no poder do Estado com uma potência cada vez maior, o partido aceita os atos de seus representantes apenas para manter a bancada e a vontade destes prevalece sobre a daquele (SOARES, 1997, p.350).
\end{abstract}

A ausência de fidelidade partidária, portanto, leva o representante do povo a agir conforme seu próprio arbítrio, no mais das vezes em detrimento do povo e em benefício de interesses escusos ao público. Os parlamentares atuam não como membros de um partido político, mas como parlamentares independentes.

Bem assevera Reale (1987, p. 94-97):

A carência de quadros partidários institucionalizados priva-nos de canais seletivos de pretensões, de tal modo que todas as reivindicações convergem para a Presidência da República, através do contato pessoal de dezenas de deputados e senadores, lídimos intérpretes de uma política de clientela. Em outra passagem encontramos: é irrecusável que o presidencialismo em vigor, concentrando imensos poderes nas mãos do Presidente da República, tem favorecido a política personalista, e constituído um dos fatores determinantes da ausência de verdadeiros partidos nacionais, em geral conglomerados de múltiplas opiniões e interesses.

O Brasil precisa corrigir diversos defeitos institucionais, e a representação política, via partidos políticos, é uma delas.

Ao analisar a troca de partidos pelos parlamentares paranaenses no período 1987 a 1997, Lepre(2000, p.94) afirma que a partir da leitura dos dados sobre trocas de legenda no período compreendido entre três legislaturas, constata-se uma intensa migração partidária, a qual dificulta a consolidação do sistema partidário no estado do Paraná, o que, por sua vez, acarreta a fragilidade do sistema partidário. $\mathrm{O}$ mesmo autor cita passagem contada por Serra, de triste realidade:

Assim se manifestou um político sobre as migrações partidárias: 'o frenesi de mudanças partidárias ocorre porque os partidos (a maioria) tendem a ser meros cartórios, que detêm dois recursos: os horários gratuitos na $\mathrm{TV}$ e o acesso às benesses governamentais. Fechando o círculo, o caráter flutuante de sua população de políticos enfraquece os partidos e reforça seu papel cartorial: passam a expressar não os setores da sociedade, mas os interesses de políticos em busca de perpetuar sua própria condição (LEPRE,2000, p. 94).

A representação acaba totalmente degenerada. Esse papel cartorial dos partidos, consequiência, em boa medida, da ausência de fidelidade partidária, proporciona 
o "agenciamento" de cargos e o respectivo controle do chefe do Executivo sobre os agenciados. Nossa democracia tem avançado muito nos últimos anos, mas o controle pelo Executivo dos cargos e seus exercentes ainda é muito grande e tende a permanecer, mesmo com a evolução da democracia, caso não seja quebrada essa aliança nefasta entre infidelidade partidária e distribuição de cargos pelo Executivo.

Somando os dois ingredientes, encontramos no Brasil um "super" presidente da República, dotado de atribuições bastante para torná-lo senhor absoluto do governo, das orientações governamentais, dos caminhos do Estado, muito além do que já ocorre no presidencialismo tradicional.

\section{A tripartição do Poder no presidencialismo de hoje}

Diante dos elementos examinados, percebemos que a teoria da tripartição do Poder foi fundamental para o surgimento do presidencialismo. Contudo, o chefe do Executivo avançou sobre as competências do Legislativo, chegando mesmo a transferir, em alguns países, como é o caso do Brasil, grande parte da produção da lei para o órgão que deveria ter como atividade principal a execução dela. Esse avanço vem por diversos motivos, entre os quais registramos o surgimento do Estado Social, o que determinou uma interferência mais ampla do governo nas questões sociais e econômicas. Com efeito, essas questões exigiam do Poder Legislativo uma dinâmica que ele não possuiu. Além disso, os meios de comunicação surgem elevando a figura do chefe do Poder Executivo, de quem o povo cobra comportamentos, mas a quem dá respaldo na disputa pela hegemonia entre os órgãos do Estado.

O Legislativo, por seu lado, não tem conseguido cassar presidentes, por toda sua história. São dois casos conhecidos. O impeachment não tem se apresentado como instrumento de controle do presidente.
Assim, os desmandos do presidente têm sido cada vez maior, por onde ele exista, e tem avançado de tal modo sobre as competências do Legislativo, pelo mundo a fora, que as ditaduras têm tomado boa parte da história dos países que adotam esse sistema de governo. A tripartição do Poder nos Estados Unidos parece subsistir em razão de uma prática persistente dos mecanismos de freios e contra pesos. Em boa parte do mundo, porém, e especialmente em nosso país, os pesos de equilíbrio entre os Poderes estão com tara maior no prato do Executivo.

\section{O presidencialismo brasileiro e controle do Poder Executivo sobre a produção legislativa}

Depois de tudo o que foi visto no início deste trabalho, podemos registrar, nesta passagem, o controle exercido pelo Executivo brasileiro sobre a produção legislativa. Podemos, tranquiilamente, firmar tal declaração por dois motivos: primeiro, em razão das características do próprio presidencialismo, que já concentra as decisões nas mãos do presidente, dando hegemonia a este órgão, na organização do Estado; segundo, em razão de peculiaridades do nosso sistema presidencialista, com muitas características do parlamentarismo, sem, até mesmo, um mecanismo apropriado para atribuir responsabilidade ao chefe do Executivo quando este abusa de suas competências.

Encontramos em Reale(1960, p.321) passagem muito importante para nosso raciocínio:

Impossível é reconhecer o primado do poder legislativo, pois "função legislativa " e "poder legiferante" não coincidem, sendo a lei geralmente o resultado de uma colaboração harmônica de poderes e esta função vai cada vez mais assumindo uma feição eminentemente técnica. Tempo houve em que não se admitia nem mesmo a crítica da doutrina da separação dos poderes, e, na forma em que ela era exposta, estava como que implícito o primado do Legislativo, restando ao Govêrno o papel secundário de executar o que tivesse sido estatuído pelo legislador parlamentar. Hoje em dia, entretanto, poucos se mantém apegados ao dogma da divisão dos poderes, e a nossa história constitucional nos dá um exemplo característico das modificações sofridas pela doutrina, desde a sua

\footnotetext{
5 Em estudo interessante sobre a função reguladora do Poder Executivo, de Mônica Nicida Garcia, encontramos fundamentos doutrinários para essa assunção da produção de normas pelo Executivo - in Cadernos de Direito Constitucional e Internacional, nº38, jan./mar.de 2002, pp. 205 a 233.
} 
primeira formulação clássica até à Constituição Federal vigente, na qual a discriminação dos poderes soberanos não tem mais o valor de um princípio essencialmente destinado à garantia das liberdades individuais, mas antes o valor pragmático de uma distribuição de funções, de uma simples aplicação da lei da divisão do trabalho no setor das atividades políticas .

Aquele que era originariamente o maior mister do órgão legislativo, com o desenvolver da história acabou manietado pelo Executivo, principalmente no Brasil. ${ }^{5}$ Exemplo disso é o uso da lei delegada. Apropriada ao modelo presidencialista, que dá hegemonia ao Executivo, é pouquíssimo usada em nosso país, pois temos a medida provisória, que amplia ainda mais a força do presidente. Não há razão para acreditar que o presidente vá usar a lei delegada quando ele pode editar medida provisória. Além disso, a iniciativa de lei dada ao presidente conjugada com o poder de veto, a infidelidade dos filiados aos partidos políticos conjugada com a distribuição dos cargos públicos, tudo isto tem feito do Executivo o órgão que concentra as decisões do Estado. No ano de 2002 , até maio, $88,5 \%$ dos projetos de leis aprovados na Câmara dos Deputados e 61,7\% dos aprovados no Senado eram de iniciativa do presidente. No ano anterior o número foi de $84 \%$, na Câmara. ${ }^{6}$

O Legislativo deixou de ser órgão responsável pela produção da lei e passou a ser fiscal do Poder Executivo. Fiscal, aqui, não apenas em relação às questões administrativo-financeiras, mas em relação a produção da lei, ou seja, a função legislativa já não é exercida, em sua essência, pelo Legislativo, pois o controle das decisões, na produção da lei, está enfeixado, em boa medida, nas mão do presidente. Isto fica ainda mais marcado quando analisamos a dinâmica do mundo contemporâneo, onde as questões debatidas no Legislativo são cada vez mais técnicas e ricas em detalhes, além de exigirem soluções "urgentes", diante da globalização e da nova dinâmica social, política e econômica daí emergente.

\section{Poder Legislativo e controle sobre o Poder Executivo: controle da legalidade e controle político}

A Constituição dá ao Legislativo um conjunto enorme de instrumentos para efetivar controle sobre o Poder Executivo (Citamos a seguir alguns deles, os principais, encontrados na Constituição: art. 49, V, IX, X; art. 50, $\$ 2^{\circ}$; art. 51, I, II; art. 52, I, V, VI, VII, VIII; art. $58, \S 3^{\circ}$, arts. 70,71 e 72 ; art. 85 , I a VII e parágrafo único; art. $86, \S 1^{\circ}$, I e II, $\S \S 2^{\circ}$ a $4^{\circ}$; art. $166, \S 1^{\circ}$, I e II). Esses instrumentos não serão discutidos aqui, por não ser este o objetivo maior de nosso estudo, nossa preocupação é quanto a possibilidade de controle do Poder Executivo num ambiente político. Aqueles são instrumentos que viabilizam este controle. Porém, estudá-los é tarefa de outra monografia. As conclusões quanto a nossas preocupações somente dependem, neste instante, de conhecermos os limites jurídicos e o ambiente político, na utilização daqueles instrumentos acima citados.

Os limites jurídicos encontramos no art. $5^{\circ}$, II da Constituição. É o princípio da legalidade: ninguém será obrigado a fazer ou deixar de fazer alguma coisa senão em virtude de lei. Assim, embora o Poder Executivo seja o maior responsável pelos destinos do Estado, em razão de sua atuação como chefe de governo, o que pressupõe ampla margem discricionária, seus atos não são arbitrários, eles devem ficar circunscritos no ambiente previamente estabelecido na Constituição e na Lei. Logicamente não somos ingênuos para pensar que esta idéia resolva o problema, como num passe de mágica. Mas importante, neste instante, é a verificação da existência de limites jurídicos para a prática de atos pelo Poder Executivo. Os limites específicos de cada ato varia conforme $o$ ato que esteja sendo praticado, daí a necessidade do estudo de cada um daqueles mecanismos de controle previstos na Constituição, acima indicados em nota de rodapé.

\footnotetext{
${ }^{6}$ Folha de Londrina, domingo, 19 de maio de 2002, p. 4, do primeiro caderno.
} 
O controle da legalidade deve ser realizado, num Estado Democrático de Direito, pelo Poder Judiciário. Porém, alguns dos instrumentos de controle podem ser utilizados pelo Poder Legislativo (nos termos do arts. 49, X e 70) e até mesmo pelo próprio Executivo, quando do controle interno, hierárquico. Mas, tendo em vista a exigência de interpretação da lei, o controle da legalidade, em última análise, deve ser realizado pelo Judiciário.

Quanto ao ambiente político, de controle do Poder Legislativo sobre o Poder Executivo, devemos estudar a discricionariedade autorizada àquele órgão para efetivar tal controle.

O Poder Legislativo realiza um controle político, quando autorizado por liberdade discricionária. $\mathrm{O}$ controle político é, exatamente, o controle realizado dentro de liberdade, dentro de poder discricionário, ou seja, conforme conveniência e oportunidade autorizada e limitada em lei. A Constituição dá ao Legislativo, nesses casos, liberdade para decidir determinada questão, podendo optar por uma dentre duas ou mais decisões. São circunstâncias previstas na Constituição (princípio da legalidade respeitado), autorizadas ao Legislativo para evitar abusos do Executivo.

Como exemplo, podemos citar a cassação do Presidente da República. Falando dessa liberdade quando do julgamento do Presidente da República, Bastos (1997, p.372) explica: "Não é imperativo da lei o que decide. Mas a conveniência aos interesses da nação, a oportunidade da deposição - do Presidente -, ainda que merecida “. O imperativo de lei não decide aquilo que deva ser solucionado entre um sim ou não, dentro de uma margem de liberdade, mas é margem de liberdade para a autoridade, é limite para decisão.

Esse controle político, efetivado com liberdade discricionária, por vezes recai sobre uma mera conduta, um mero comportamento do Presidente (por exemplo, quando a Câmara dos Deputados autoriza o julgamento do Presidente por prática de crime comum). Por vezes, o controle recai sobre atos do
Presidente baixados também com poder discricionário, ou seja, nestes casos ao poder discricionário do Presidente é anteposto o poder discricionário do Legislativo, para avaliar politicamente os excessos cometidos por aquela autoridade, como é o caso do exame do decreto de intervenção federal pelo Congresso Nacional. Transcrevemos a seguir passagem excepcional de Bastos (1994a, p.335), sobre o assunto:

A palavra 'controle' traz bem consigo a idéia de aferição de um ato com um padrão, conferir um ato com as disposições legais, a fim de verificar se há adequação. Todavia, é certo que existe também o controle dos atos discricionários onde este padrão não está rigidamente definido na lei. Enquanto nestes atos conjuntos não existe nenhum padrão; é o que poderíamos chamar de exercício de uma atividade política. É por isso que alguns autores até falam em controle político, com relação ao que não teríamos nada a opor. Contudo, achamos que esse controle político não é da alçada do direito administrativo; diz mais respeito a todo o sistema de separação de Poderes existente .

Assim, portanto, o controle realizado pelo Congresso Nacional sobre as atividades do chefe do Poder Executivo tem dimensão constitucional e não se reduz à esfera administrativa. É o âmbito da tripartição do Poder, de controle do poder pelo Poder, controle do exercício do poder pelas próprias estruturas de exercício do poder.

Neste campo não estamos nos limites estreitos da legalidade, estamos no campo político, onde o confronto de forças determina a solução em uma disputa. Para a manutenção de uma democracia, é necessário criar mecanismos que proporcionem o equilíbrio nessa disputa. $\mathrm{O}$ poder somente pode ser controlado pelo próprio poder. A inexistência de mecanismos que mantenham o equilíbrio nessa balança leva ao arbítrio, a ditaduras, a abusos do poder de modo desmedido.

Depois de tudo já estudado sobre a concentração de competências nas mãos do presidente da República, não é difícil concluir que o Legislativo brasileiro não tem forças suficientes para fazer frente 
a um presidente ardiloso. Uma das funções fundamentais do Legislativo é fiscalizar o atos do presidente, mas em nosso sistema de governo isto é uma quimera. Esse papel tem sido realizado pelo Ministério Público, com excelentes resultados, mas este órgão não é um Poder do Estado e o controle do poder, em suas últimas consequiências, somente pode ser realizado pelo próprio poder.

O Legislativo deve adquirir mecanismos apropriados para a defesa dos interesses do povo, ou ele continuará submisso ao Poder Executivo. Nesta segunda hipótese nada evita o arbítrio, nem mesmo a ética dos parlamentares, pois o poder, conforme ensina Montesquieu, exercido sem controle, tende ao arbítrio em detrimento das liberdades.

Presidencialismo, predominância do Poder Executivo sobre Legislativo e Judiciário e fragilidade democrática no Brasil

Depois de examinadas as características do presidencialismo em razão da tripartição do poder, chegamos à última delas, a predominância do Poder Executivo sobre os demais Poderes do Estado. Muitos autores não a apresentam como característica do sistema, por ser, na verdade, conseqüência das demais características já citadas neste trabalho. No entanto, o funcionamento do sistema pressupõe uma superioridade do Executivo em relação aos demais Poderes. Embora o presidencialismo tenha como base o equilíbrio entre os órgãos fundamentais de poder do Estado, há hegemonia do Executivo. Essa hegemonia, contudo, não pode ser de tal monta que inviabilize o controle do poder pelos demais órgãos que exercem o poder.

Essa predominância existe em razão de inúmeras competências atribuídas ao presidente. São competências necessárias para o bom funcionamento do sistema, mas têm por consequiência a submissão dos demais Poderes ao chefe do Executivo. Das características do presidencialismo já apresentadas, verifica-se a predominância do Executivo, especificamente no Brasil, em razão das seguintes: participação do presidente na produção legislativa, podendo, inclusive, criar lei delegada, medida provisória, propor e vetar projetos de lei; o mandato fixo e o impeachment, com toda a dificuldade para a cassação do presidente; a irresponsabilidade política do presidente; o presidente como chefe de governo, autoridade competente para determinar a orientação política do Estado, a orientação governamental; a ausência de fidelidade partidária e a distribuição dos cargos públicos realizada pelo Executivo.

Encontramos passagens significativas na doutrina, esclarecedoras da supremacia do Executivo sobre os demais órgãos do Estado. Para Ferreira Filho (1999, p.140) os traços políticos de um sistema são, talvez, de maior importância que os estritamente jurídicos: $\mathrm{O}$ principal deles no presidencialismoé, como se pode supor, a predominância do Presidente .

Para Bastos(1994a, p.158):

em boa parte das ocasiões, o presidencialismo recobre uma realidade autoritária de um chefe de Estado despótico, isto em razão do engrandecimento do Executivo, das suas competências, dos seus poderes. Ocorre, na maioria dos casos, que o Legislativo e o Judiciário não podem acompanhar na mesma proporção essa ascensão do Poder Executivo, que passa a deter uma soberania tranqüila sobre os demais poderes.

A predominância do Executivo no presidencialismo, portanto, depende do ambiente político em que ele existe, viabilizado, logicamente, por instrumentos jurídicos, acima citados. Não é demais lembrarmos Montesquieu: o poder exercido de modo ilimitado tende ao arbítrio em detrimento das liberdades; para evitar tal tendência é preciso o controle do poder pelo próprio poder.

Esses dados encontramos em outros autores. Para Menezes(1999, p.318) a marca individual que o presidente imprime aos acontecimentos estatais é um dos pontos cardeais do presidencialismo, essa "influência pessoal do chefe do executivo diz respeito à independência com que ele desempenha as suas altas e imensas atribuições". Não é exagero do autor. Essa marca individual impressa pelo chefe do Executivo nos destinos do Estado é uma das características do presidencialismo. E, ainda podemos 
dizer, é aquela que apresenta maior dificuldade de adequação para o bom funcionamento do sistema de governo.

Segundo Russomano(1997, p.128), os norteamericanos estabeleceram uma modalidade de regime de governo pelo qual o centro de atividade política se localizou no chefe do Executivo, ou seja, no Presidente da República . Essa característica está, assim, na origem do sistema.

Entre os norte americanos, Schwartz(1966, p.114115) explica que:

os dispositivos concernentes ao poder executivo, na Constituição federal, são judiciosamente redigidos em termos gerais. Isso tem permitido que o poder presidencial se expanda para atender às necessidades de emergência, enquanto garante a sua contração nas ocasiões menos tensas. [...] Certamente, os sistemáticos fluxos e refluxos do poder presidencial falam em favor dos elaboradores da Constituição americana nos seus esforços a fim de resolver o problema a que nos referimos, o de estabelecer um Executivo bastante forte para pelejar pelos interesses da nação, mas não tão forte que a nação não possa pelejar contra ele .

Esse equilíbrio encontrado na prática norte americana dificilmente é encontrada em outro país. $\mathrm{O}$ mundo assimilou as formalidades do sistema presidencialista. Seu funcionamento, contudo, não depende apenas de mecanismos formais. Depende da cultura em que viceja esse presidencialismo, assim como do ambiente democrático sobre o qual ele se sustenta.

No caso brasileiro, especificamente, o presidencialismo tem se mostrado como instrumento apropriado para o surgimento de ditaduras. Ele tem sido tão eficiente nesse caminho que sequer podemos dizer que o Brasil conheceu realmente uma democracia. Isso porque o povo teve poucos espaços de liberdade política para afirmarmos a existência de uma prática democrática eficiente. Democracia depende de aprendizagem e isso não ocorre de um dia para outro. A predominância do chefe do Executivo no presidencialismo é característica do sistema. Contudo, essa proeminência do presidente não pode ser apenas um caminho de ida. Conforme ensina Bernard Schwartz, o bom funcionamento do sistema conhece fluxos e refluxos. Esta lição ainda não foi assimilada por nossa prática presidencialista e talvez esse sistema não sobreviva tempo suficiente para chegarmos a aprendê-la um dia.

O presidencialismo brasileiro não traz segurança democrática. Pelo contrário, dependemos muito da pessoa que exerce o cargo de chefe do Executivo. São tantas competências, tantas atribuições, tanto poder nas mãos de um único homem, tudo isto garantido por um mandato fixo, com prazo certo, que dificultam a certeza quanto aos comportamentos das Instituições nacionais. A hegemonia do Executivo é exagerada em nosso país. $\mathrm{O}$ presidente não pode ser controlado a contento pelos demais Poderes do Estado, porque estes sucumbem diante da força daquele sujeito. Nossa democracia ainda depende muito de pessoas, nossas Instituições ainda são bastante vulneráveis. A tristeza é maior quando se verifica que a prática "de nossas pessoas", dos nossos políticos está muito próxima da corrupção. Mas isto não é tema deste estudo, é apenas uma verificação, aqui, que agrava os problemas coletados no ambiente jurídico.

\section{Presidente: Chefe de Estado e Chefe de Governo}

Uma das principais características a ser salientada no presidencialismo é a outorga de duas missões a um único indivíduo, quais sejam, a chefia de Estado e a chefia de governo. Poder-se-ia ter escrito "outorga de duas funções a um único indivíduo", contudo, como se verá adiante, cada uma dessas atribuições do Poder Executivo contém mais de uma função. Essas duas atribuições transformam o titular do cargo de chefe do Poder Executivo em alguém que centraliza as decisões dentro do Estado.

É de fundamental importância esclarecermos essas funções do Executivo, para continuidade do nosso estudo. Quando falamos em controle do chefe do Poder Executivo, é preciso estabelecer com 
precisão suas funções, suas atividades básicas. É a partir dessa dualidade de atribuições dadas ao presidente, chefe de Estado e chefe de governo, que tem origem todas as funções dadas a ele.

Encontramos em Dallari (1991, p.204) uma noção básica, pela qual o mesmo órgão acumula duas atribuições, exercendo o papel de vínculo moral do Estado e desempenhando as funções de representação, ao mesmo tempo em que exerce a chefia do poder executivo . Enquanto chefe de Estado, portanto, cabe ao presidente, por um lado, possibilitar um vínculo moral dentro do Estado (idéia vinda da monarquia, na qual o rei cumpre esse papel, por não precisar de disputas políticas para obter o cargo), de outro lado, cabe a ele a representação do Estado, tanto interna como externamente. Enquanto chefe do governo, cabe a chefia do Poder Executivo, nos termos colocados pelo autor citado.

Verificamos grande dificuldade para estabelecer as funções justamente do chefe do Poder Executivo. Aqui concentra-se as funções de maior repercussão desse sujeito. Contudo, isso não tem sido devidamente explicado, no Brasil. Segundo Schwartz(1996, p.141) "as funções do chefe de um Estado soberano" significando, aqui, chefe de um país, não apenas Chefe de Estado -, de modo geral, enquadram-se em duas categorias: política e administrativa. Continua o autor, citando Willoughby: Nos diferentes países, a importância que se dá a cada uma dessas funções varia. Em alguns, os poderes e a influência do chefe do Executivo são quase inteiramente políticos; em outros, como a Suíça, a importância principal se acha no setor administrativo

Excluindo-se as competências do chefe do Executivo enquanto chefe de Estado (competências que também se enquadram como questões administrativas ou políticas, mas restritas a possibilidade de se firmar um vínculo moral e a representação do Estado), encontram-se as competências do chefe de governo. Assim, cabe ao presidente tanto função administrativa, de execução da lei, como função política, de orientação das decisões do Estado.
Dentre essas atribuições do chefe do Poder Executivo, este estudo deve esclarecer quais são as funções do chefe de governo. É justamente aí que reside nossa preocupação inicial, onde os efeitos da atuação desse sujeito podem ser altamente danosos para o povo e para a democracia. Daí a necessidade de balizá-las.

Nossos estudiosos do Direito têm apresentado estudos magníficos quanto ao controle da legalidade dos atos do presidente, no âmbito de sua competências meramente administrativas. Isto parece decorrer dos períodos de ditaduras conhecidos em nosso país, dos abusos praticados por autoridades que desconheceram totalmente o que seja Estado de Direito ou, ao menos, princípio da legalidade. Mas as atribuições do presidente não estão reduzidas a administração do Estado.

Este estudo não pretende restringir-se ao controle da administração propriamente, no sentido de estreito controle de legalidade. Isto é tema de Direito Administrativo, já bastante debatido em nosso país e com altíssima qualidade. Nosso exame está fincado no campo do Direito Constitucional, ainda com poucas linhas sobre controle da administração, no sentido de controle político do Poder Executivo.

Nossa doutrina jurídica parece esquecer que também cabe ao presidente uma função política, demarcada sim pelo princípio da legalidade, mas de vasta liberdade de atuação, de larga margem de liberdade, ou seja, de ampla discricionariedade.

Quando falamos em controle dos atos do chefe do Poder Executivo não se pode nos restringir ao controle da estrita legalidade de seus atos. Deve-se ir além, precisamos demarcar os limites de atuação política dele. Isso, evidentemente, não foge do âmbito da legalidade, mas dá margem de liberdade ampla à autoridade que pratica o ato. Passar-se-á, então, ao exame do que seja essa atuação política do presidente da República, para, posteriormente, chegarmos a uma conclusão acerca da característica do presidencialismo que reúne chefe de Estado e chefe de governo na mesma pessoa. Vamos verificar, então, o que é governo e ato político. 
No âmbito dessa atuação política, o presidente pratica atos políticos. Este estudo está no campo da Ciência do Direito. Ato político aqui não significa apenas ato de vontade do presidente, mas é ato jurídico, tipicamente demarcado pela lei, manifestado expressamente, motivado fundamentadamente. É uma das espécies de ato jurídico.

O ato político não é um desses temas acerca do qual se tem vasta bibliografia. Pelo contrário, a bibliografia é escassa. A compreensão do ato político, por outro lado, depende do estudo de alguns temas sobre os quais a doutrina não chegou a um consenso. $\mathrm{O}$ próprio conceito de ato político ainda não tem contornos seguros e talvez sequer chegue a ter um dia, em razão de envolver elementos muito genéricos.

Segundo Meirelles(1991, p.604): “Atos políticos' são os que praticados por agentes do Governo, no uso de competência constitucional, se fundam na ampla liberdade de apreciação da conveniência ou oportunidade de sua realização, sem se aterem a critérios jurídicos preestabelecidos. Ainda completa o autor: São atos governamentais por excelência, e não apenas de administração. São atos de condução dos negócios públicos, e não simplesmente de execução de serviços públicos .

O conceito traz o critério formal como base, pressupondo competência fixada na Constituição, mas fala em "agentes do Governo", generalizando a autoridade que os pratica. $\mathrm{O}$ conceito ainda inclui outro elemento: o poder discricionário, quando diz que $o$ ato se funda na amplo liberdade de apreciação da conveniência ou oportunidade de sua realização. A discricionariedade pode ser encontrada no ato administrativo, porém o autor faz menção a uma ampla liberdade de apreciação, ou seja, trata-se de um ato praticado dentro de uma extensa margem de liberdade, muito além daquela encontrada normalmente na produção do ato administrativo.

Para Mello(2000, p.342), "Atos políticos ou de governo", praticados com "margem de discrição e diretamente em obediência à Constituição", no exercício de função puramente política .

São três as características do ato político, citadas pelo autor: é ato discricionário; tem seu fundamento de validade fincado na Constitucional; é praticado no exercício de função política. Isso merece realce, Celso Antônio traz o ato político como sendo aquele praticado no exercício de função política.

Dos conceitos colacionados, percebe-se que o ato político tem seu fundamento de validade na Constituição, ao contrário do ato administrativo que tem seu fundamento de validade na lei, situação característica da função administrativa. Explica-nos Silva(2000, p.111):

Os órgãos do Estado são 'supremos'
(constitucionais) ou 'dependentes'
(administrativos). Aqueles são os a quem incumbe
o exercício do poder político, cujo conjunto se
denomina 'governo' ou órgãos governamentais.
Os outros estão em plano hierárquico inferior, cujo
conjunto forma a Administração Pública,
considerados de natureza administrativa. Enquanto
os primeiros constituem objeto do Direito
Constitucional, os segundos são regidos pelas
normas do Direito Administrativo.

Desse modo, a compreensão do ato político, nesse ambiente, passa pelo conceito de governo. $\mathrm{O}$ ato político - ou ato de governo, denominação também aceita pela doutrina - é um ato praticado para o cumprimento da Constituição, ou seja, diz respeito ao exercício do poder do Estado, e conhece apenas os limites postos pelo Poder Constituinte originário. Está muito além da execução da lei, própria da função administrativa (onde também há manifestação de poder do Estado, restringida já, aqui, pela lei). Para compreender, portanto, o objeto deste estudo, é fundamental entender o que seja governo.

Pode-se entender a expressão governo como condução dos interesses do Estado. Diz respeito a condução dos negócios de um povo situado em determinado território, tendo em vista o bem comum dessa sociedade estatal. A condução desses negócios se dá pela ação humana, por atos do homem denominados atos políticos. Essa noção básica, contudo, esconde um debate doutrinário enorme, a respeito do que seja governo. 
Em primeiro lugar, é preciso estabelecer a diferença entre administração e governo, tema discutido por Ferreira Filho(1999, p.22):

A administração civil é aquela seção do Executivo, de caráter subordinado, hierarquizado e não militarizado, que prepara, acompanha a execução ou executa por si leis e outras resoluções políticas, que não toma.

O seu caráter subordinado a distingue do governo propriamente dito. Este é que decide politicamente, escolhendo fins e meios. Estes fins e meios são os dados de onde parte o trabalho da administração. Sem dúvida, esta, por seus serviços técnicos, colabora no preparo e formulação das diretrizes políticas. Essas diretrizes são obrigatórias, não porque as assessorias assim entenderam, mas porque um órgão com poder decisório o quis e destarte as encampou .

Di Pietro (1992, p.49) explica a função política ou de governo citando Renato Alessi, para quem tal função implica uma atividade de ordem superior referida à direção suprema e geral do Estado em seu conjunto e em sua unidade, dirigida a determinar os fins da ação do Estado, a assinalar as diretrizes para as outras funções, buscando a unidade da soberania estatal .

Silva, enfim (2000, p. 112), sintetiza:

O "governo" é, então, o conjunto de órgãos mediante os quais a vontade do Estado é formulada, expressada e realizada, ou o conjunto de órgãos supremos a quem incumbe o exercício das "funções do poder político". Estes se manifestam mediante suas funções que são exercidas e cumpridas pelos órgãos de governo. Vale dizer, portanto, que o poder político se desdobra e se compõe de várias funções, fato que permite falar em 'distinção das funções', que fundamentalmente são três: a legislativa, a executiva e a jurisdicional .

Governar, portanto, não é tarefa exclusiva do Poder Executivo. A atividade governamental está distribuída por todos os órgãos do Estado, onde quer que haja uma manifestação legítima-legitimidade constitucional - de condução dos negócios do Estado. Aparentemente essa manifestação da vontade do Estado está fixada no Executivo, mas isto não é correto:

No direito brasileiro, de regime presidencialista $\mathrm{e}$ com grande concentração de poderes nas mãos do Presidente da República, é justificável a tendência de identificar-se o Governo com o Poder Executivo. [...] Pode-se dizer que no direito brasileiro as funções políticas repartem-se entre Executivo e Legislativo, com acentuada predominância do primeiro. Ao contrário dos Estados Unidos, onde o Poder Judiciário desempenha papel de relevo nessa área, no Brasil a sua atuação restringe-se, quase exclusivamente, à atividade jurisdicional, sem grande poder de influência nas decisões políticas do Governo (DI PIETRO, 1992, p. 51).

Encontramos em Loewenstein (1970, p. 36) ${ }^{7}$ uma explicitação daqueles que ele chama de detentores do poder oficial e visível. São quatro detentores do poder: o Governo - caracterizado pelo Poder Executivo, dentro da teoria da Tripartição do Poder - encarregado, dentro do Estado constitucional, das funções governamentais de tomar e executar as decisões; o Parlamento, encarregado da legislação e da função de controlar o governo; os destinatários do poder que, ao se organizarem nos quadros dos partidos políticos se elevam à condição de um detentor do poder, além de participar diretamente através de eleições, referendo e impacto da opinião pública nos órgãos estatais; finalmente, os Tribunais, em situações excepcionais, quando declaram inválidas as leis emitidas pelo Parlamento e pelo Governo (controle judicial da constitucionalidade das leis).

Voltando nossa atenção para o Poder Executivo, pode-se dizer que a concentração da vontade do Estado neste órgão não existe somente no Brasil, embora entre nós se tenha exagerado na dose. Em verdade, essa concentração é própria do Estado intervencionista do séc. XX, da sociedade pluralista de massas do nosso século (LOEWENSTEIN, 1970, p. 62) onde este órgão teve seu campo de atuação alargado.

\footnotetext{
${ }^{7}$ As partes com citação textual têm tradução do autor deste artigo.
} 
Ora, essa extensão foi principalmente uma ampliação das tarefas assumidas pelo Executivo. A este é que coube criar e gerir os serviços assistenciais, tomar o leme da vida econômica e financeira, impulsionar e mesmo dirigir os serviços públicos essenciais espaldando ou substituindo a iniciativa privada, fraca ou inexistente. Tudo isso recaiu sobre seus ombros porque sua estrutura concentrada lhe permitia as decisões prontas que nesses campos são necessárias (FERREIRA FILHO, 1999, p. 217).

Assim, apesar da atividade governamental concentrar-se entre as competências do Poder Executivo, ela está distribuída pelos diversos órgãos do Estado, tanto pelo Executivo, como pelo Legislativo e Judiciário. Por outro lado, também se deve incluir aí a manifestação da vontade popular, na condução dos negócios e interesses do Estado. Afinal de contas, o art. $1_{-}^{\circ}$, parágrafo único da Constituição estabelece que todo o poder emana do povo, que o exerce por meio de representantes eleitos ou diretamente, nos termos da própria Constituição.

O povo participa do governo quando elege representantes, escolhendo um programa liberal, socialista ou seja lá o que for. Também participa através de plebiscito, de referendo e de iniciativa popular. Por último, ainda podemos dizer que o povo participa da orientação política do Estado em suas diversas manifestações, como por exemplo, nos sindicatos, nas greves, nas passeatas, participando das convenções partidárias, escrevendo nos jornais, enfim, sempre que toma uma posição frente a uma decisão do Estado, já que de algum modo isto acaba refletindo nas decisões oficiais do Estado.

Como conclusão deste capítulo, pode-se dizer que o Direito não deve se perder em estruturas subjetivas, imprecisas, onde pode haver fácil manipulação viciada da lei. O Direito exige a objetividade, embora isso nem sempre seja possível, que deve ser buscada em meio a interesses e vontades. Por causa disso, entende-se que o ato político é aquele que emana diretamente da Constituição, tendo, portanto, limites formais. Contudo, a idéia simples de ato infra constitucional não nos parece suficiente para efetivar um controle do ato político. Para tanto, é necessário embutir no conceito de ato político a idéia de governo.
Fundamental é a noção de que no Poder Executivo está embutida, também, a função governamental, ou seja, a condução dos interesses do Estado.

O ato político ou de governo é infra constitucional. Seu controle, portanto, tem os contornos objetivos exigidos pelo Direito. Contudo, a idéia de governo incorporada no ato político é fundamental para a interpretação da norma jurídica diante do caso concreto.

Como bem explica Oliveira (1980, p. 138-139), citando Miguel S. Marienhoff e depois Dromi, o regime jurídico do ato político obedece a princípios similares aos do ato administrativo e não podemos chegar ao extremo de entender que devam reger-se por distintos critérios jurídicos. Do mesmo sentir é Dromi ao afirmar que 'la causa diferenciador entre las actividades políticas y administrativa, es una cuestión de grado o de intensidad'. No Brasil, porém, o controle do ato administrativo não tem encontrado soluções razoáveis, e ainda piores são as soluções para o ato político.

As funções do chefe do Poder Executivo enquanto chefe de governo são distribuídas entre atividades administrativas e atividades políticas. No desempenho de função administrativa ele executa a lei, com atuação balizada pela lei, dentro de limites estreitos de liberdade. No desempenho de função política, porém, apesar de mantidas as balizas da lei (fincadas principalmente na Constituição), ele tem ampla margem de liberdade e o controle de seus atos tornase complexo, já que a função política do presidente está a esbarrar, a todo instante, com interesses do povo, do Legislativo e do Judiciário, os quais também possuem o que podemos chamar de competência governamental.

Nesse ambiente, o chefe de governo conduz os interesses do Estado, embora não o faça sozinho, mas tem sempre prevalência nesse mister. O controle do ato político e a condução dos negócios do Estado (governo), conduzidos pelo chefe de governo, somente será possível enquanto for mantido o equilíbrio entre os Poderes. Caso o Executivo sobressaia excessivamente entre os órgãos do Estado, o arbítrio estará muito próximo. 
No Brasil, esse equilíbrio não existe. O Judiciário procura manter distância das questões políticas e acaba apresentando decisões formais, mecanicamente legalistas, o que acaba possibilitando a manutenção da dominação por parte de quem já detém o poder. O Legislativo, como já estudado no primeiro capítulo deste trabalho, está manietado às garras do Executivo. O povo, está distante das questões de Estado. Presidencialismo e democracia, no Brasil, é um casamento improvável, registrado em determinados períodos apenas em razão de pessoas e circunstâncias, não em razão das Instituições.

\section{Poder Executivo Unipessoal}

Outra característica bem demarcada no presidencialismo é a existência de um órgão Executivo unipessoal, ou seja, a responsabilidade pela fixação das diretrizes do poder executivo cabe exclusivamente ao Presidente da República (DALLARI, 1991, p. 204). O presidente enfeixa em suas mãos, com exclusividade, a soma total das funções que a Constituição atribui a esse Poder (MALUF, 1990, p. 244). Oficialmente não cabe a nenhuma outra pessoa, senão ao presidente, a responsabilidade quanto aos atos e práticas desse órgão.

Para cumprir suas obrigações, o presidente tem um corpo de auxiliares, os ministros. As práticas de cada um destes, contudo, depende da aquiescência, implícita ou explícita, do presidente. $\mathrm{O}$ cargo de ministro é de confiança e eles permanecem em seus cargos enquanto mantenham essa confiança.

O órgão é, realmente, unipessoal. Ao chefe do Executivo incumbe tomar as decisões de competência do órgão. Ainda que auxiliado por diversas pessoas, as diretrizes de competência do Executivo é dele, o presidente. Essa idéia ainda é corroborada pela condição em que se encontra o presidente no quadro da tripartição do Poder, pela possibilidade do veto por interesse público (aquele que existe em razão da decisão do chefe do Poder Executivo sobre o que seja interesse público) e, ainda, pela condição de chefe de governo, pela qual cabe ao presidente a orientação política do Estado. Esses temas já foram discutidos neste trabalho.
Por fim, devemos ressaltar que o Poder Executivo, no presidencialismo, é unipessoal, mas isto, ao menos em tese, não traz o desequilíbrio entre os órgãos fundamentais do Estado. O poder unipessoal é a centralização das decisões do Poder Executivo nas mãos do presidente. O desequilíbrio entre os Poderes surge em razão do excesso de competências autorizadas ao presidente, o que pode trazer o autoritarismo.

\section{Conclusão}

Como conclusão aos estudos realizados no presente trabalho, podemos apresentar as seguintes idéias:

1. Verificou-se, no presente estudo, que o presidencialismo, em sua origem, privilegiou o Poder Executivo, com o objetivo de tornar o presidente a autoridade maior dentro do Estado. Contudo, também em sua origem, propõe mecanismos de controle do poder pelo poder. Assim, embora tenha hegemonia dentro do sistema, o presidente também conhece limites que evitam abusos do cargo e concentração excessiva de poder. No Brasil, porém, o presidente, além de ter mandato fixo e a possibilidade de perda do cargo apenas por cassação recheada de entraves, também tem iniciativa de lei, espécie normativa para produzir normas (medida provisória) e poder de veto. Também tem cargos públicos para distribuir entre seus correligionários e a ausência de fidelidade partidária. Isso tudo faz do chefe do nosso Executivo um "super" presidente.

2. O problema maior do presidencialismo brasileiro não é exatamente o desequilíbrio exagerado entre os órgãos fundamentais do Estado, entre os Poderes do Estado, que existe e deve ser corrigido, mas uma consequiência desse fato, a ausência de mecanismos de controle do chefe do Poder Executivo. No Brasil, ele tem controle sobre a produção legislativa, não sofre uma fiscalização adequada do Legislativo e, ainda, dificilmente será responsabilizado por seus atos, pois o mecanismo adotado por nós (crime de responsabilidade política), próprio do 
presidencialismo, depende de grande movimentação política da sociedade e das Instituições públicas, o que é dificultado pela excessiva hegemonia mantida pelo presidente.

3. O presidencialismo brasileiro é bastante influenciado pelo sistema parlamentarista. Percebe-se que o chefe do nosso Executivo tem uma liberdade de atuação muito ampla, própria do parlamentarismo, mas somente pode ser afastado pelo mecanismo adotado no presidencialismo, de difícil sucesso.

4. O bom funcionamento do sistema depende do ambiente político onde ele vive. O presidencialismo, no Brasil, ainda depende muito da pessoa que exerce o cargo de presidente, pois a ele são autorizados inúmeros poderes (competências). Isso porque nossas Instituições políticas ainda são muito frágeis, havendo hegemonia excessiva do Executivo, em detrimento dos demais Poderes, sem mecanismos apropriados de controle dos atos do presidente.

5. Enquanto chefe de governo, o presidente tem predominância para conduzir os interesses do Estado, para determinar os caminhos do Estado. Isso ele faz por atos políticos, teoricamente controláveis pelo Judiciário e pelo Legislativo, contudo, na prática, raramente controlados pelo Judiciário ou pelo Legislativo. Em razão de excessivos poderes (competências) autorizados ao presidente, acabouse atribuindo a ele a maioria das decisões sobre os caminhos de nosso país, o que caracteriza uma atuação sobranceira em relação aos demais Poderes. Decorre daí a fragilidade democrática e, também, a dependência da pessoa que exerce o cargo de presidente, havendo grande dificuldade de controle político e até mesmo jurídico do Presidente da República no Brasil.

\section{Referências}

ACCIOLI, Wilson. Teoria geral do Estado. Rio de Janeiro : Forense, 1985.

BASTOS, Celso Ribeiro. Curso de direito administrativo. São Paulo : Saraiva, 1994a.

Curso de direito constitucional. $18_{-}^{\mathrm{a}}$ ed. São Paulo: Saraiva, 1997.
. Curso de teoria do Estado e ciência política. $2_{-}^{\mathrm{a}}$ ed. São Paulo : Saraiva, 1989.

. Dicionário de direito constitucional. São Paulo : Saraiva, 1994b.

DALLARI, Dalmo de Abreu. Elementos de teoria geral do Estado. 16_a ed. São Paulo : Saraiva, 1991.

DI PIETRO, Maria Sylvia Zanella. Direito administrativo. São Paulo : Atlas, 1992.

FERREIRA FILHO, Manoel Gonçalves. Curso de direito constitucional. 25_ed. São Paulo : Saraiva, 1999.

GARCIA, Mônica Nicida. A função reguladora do Poder Executivo. Cadernos de Direito Constitucional $e$ Internacional, São Paulo, n_o 38, pp.205-233, jan./mar. 2002.

LEPRE, Mário Sérgio. Caos partidário paranaense. Londrina : Ed. UEL, 2000.

LOEWENSTEIN, Karl. Teoría de la Constitución. $2_{-}^{\mathrm{a}}$ ed. Barcelona : Ariel, 1970.

MALUF, Sahid. Teoria geral do Estado. 20_a ed. São Paulo : Saraiva, 1990.

MEIRELLES, Hely Lopes. Direito administrativo brasileiro. 16_a ed. São Paulo : RT, 1991.

MELLO, Celso Antônio Bandeira de. Curso de direito administrativo. 13_a ed. São Paulo : Malheiros, 2000.

MENEZES, Aderson de. Teoria geral do Estado. $8_{-}^{\text {a ed. }}$ Rio de Janeiro : Ed. Forense, 1999.

MONTESQUIEU, Charles Louis de Secondat, baron de la Brèd et de. Do espírito das leis. 2a ed. São Paulo : Abril Cultural, 1979. (Coleção Os Pensadores).

OLIVEIRA, Régis Fernandes de. Ato administrativo. $2_{-}^{\mathrm{a}}$ ed. São Paulo : Ed. Revista dos Tribunais, 1980.

REALE, Miguel. Teoria do direito e do Estado. $2_{-}^{\mathrm{a}}$ ed. São Paulo : Martins Editora, 1960.

. Liberdade e democracia (em torno do Anteprojeto da Comissão Provisória de Estudos Constitucionais). São Paulo : Saraiva, 1987.

RODRIGUES, Ernesto. O veto no Brasil. Rio de Janeiro : Forense, 1981.

RUSSOMANO, Rosah. Curso de Direito Constitucional.

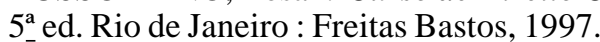

SCHWARTZ, Bernard. Direito Constitucional americano. Rio de Janeiro : Forense, 1966.

SILVA, José Afonso da. Curso de direito constitucional positivo. $17_{-}^{\mathrm{a}}$ ed. São Paulo : Malheiros, 2000.

SOARES, Marcos Antônio Striquer. O princípio da representação popular e controle jurídico sobre os atos do eleito. Cadernos de Direito Constitucional e Ciência Política, São Paulo, no 21, pp. 338-354, out./dez., 1997.

TEMER, Michel. Elementos de direito constitucional. $7_{-}^{\mathrm{a}}$ ed. São Paulo : Revista dos Tribunais, 1990. 